\title{
SOUTH AFRICAN CONSTITUTIONAL AND LEGISLATIVE FRAMEWORK ON EQUALITY: HOW EFFECTIVE IS IT IN ADDRESSING RELIGIOUS DISCRIMINATION IN THE WORKPLACE?
}

\author{
Radley Henrico \\ BProc LLB LLM \\ Senior Lecturer, Public and Procedural Law \\ University of Johannesburg \\ Advocate of the High Court of South Africa
}

\section{SUMMARY}

In the South African democratic legal system the imperative of equality is given express effect to by the Constitution. The regime pertaining to the right to equality and the adjunct right not to be unfairly discriminated against is one which is highly regulated in terms of relevant national legislation giving effect to the enforcement of equality and the proscription of religious unfair discrimination as an act which detracts from the right to equality and the inherent worth of human dignity. The ILO and its relevant instruments also play an important role in determining the manner in which national legislation interprets the right to equality in general and the right not to be unfairly discriminated against specifically. This system has given rise to a jurisprudential notion of substantive equality. The Harksen $v$ Lane case has had an appreciable impact on our case law by establishing the so-called three-stage test to determine whether unfair discrimination has taken place. Despite misgivings, the Harksen test continues to pervade our jurisprudence. An examination of three separate decisions pertaining to religious unfair discrimination suggests, however, the absence of a universal test being adopted. Courts, tribunals and fora would be encouraged when adjudicating religious discrimination disputes in the workplace to bring to the determination a context sensitive approach.

\section{INTRODUCTION}

"Equality is our Constitution's focus and its organising principle."*

The Constitution of the Republic of South Africa ${ }^{1}$ (the Constitution) speaks unashamedly of the achievement of equality. ${ }^{2}$ It expressly provides that

\footnotetext{
Per Kriegler J in President of the Republic of South Africa v Hugo 1997 (6) BCLR 708 (CC) par 74.
}

Of 1996 
everyone is equal before the law and has the right to equal protection and benefit of the law. ${ }^{3}$ It goes so far as to define equality as including the full and equal enjoyment of all rights and freedoms. Section 9 provides that national legislation is to be enacted in order to address, firstly the achievement of equality designed to protect or advance categories of persons disadvantaged by unfair discrimination ${ }^{5}$ and secondly, to prevent or prohibit unfair discrimination ${ }^{6}$ on any one of several grounds. ${ }^{7}$ Legislation aimed at achieving the promotion of equality by advancing certain categories of persons is germane to affirmative-action measures. ${ }^{8}$ Preventative and prohibitive measures against unfair discrimination in the workplace in general and religious discrimination in particular are catered for by two principal Acts, namely the Employment Equity $\mathrm{Act}^{9}$ (the EEA) and Labour Relations $\mathrm{Act}^{10}$ (the LRA).

The purpose of this paper is to focus on the significance of the South African constitutional and legislative framework on equality in addressing religious discrimination in the workplace. It will be argued that a highly regulated framework is in place, held together primarily through the constitutional enshrinement of equality which is given effect to by the EEA and the LRA. Put differently, the right to equal treatment as contained in the Constitution translates into the right an employee has not to be unfairly discriminated against by the employer on the basis of religion as provided for in the EEA and LRA. It will further be examined how the aforesaid national legislation gives effect to the International Labour Organisation. ${ }^{11}$ It will be argued that despite criticism of the ongoing application of the Harksen $v$ Lane $^{12}$ three-stage test in determining discrimination disputes that ultimately, what is important is for courts, tribunals and fora to adopt a contextsensitive approach when dealing with workplace religious-discrimination disputes.

\footnotetext{
S $1(a)$.

$S 9(1)$

S $9(2)$.

$S 9(2)$. In this regard.

S $9(3)$.

$S$ 9(3). It is submitted that the seventeen grounds listed are not exclusive, given the wording of ss (3) which states: "The state may not unfairly discriminate directly or indirectly against anyone on one or more grounds, including race, gender, sex, pregnancy, marital status, ethnic or social origin, colour, sexual orientation, age, disability, religion, conscience, belief, culture, language and birth."

8 This falls outside the ambit of subject matter of this paper, however, for further reading see Van Niekerk and Smit Law@work (2015) 153-172; and Rycroft "Transformative Failure: The Adjudication of Affirmative Action Appointment Disputes" in Dupper and Garbers (eds) Equality in the Workplace: Reflections from South Africa and Beyond (2009) 325.

1077 of 1995.

11 And its relevant Covenants.

121998 (1) SA 300 (CC).
}

955 of 1998. 


\section{LEGAL FRAMEWORK}

\section{Constitutional imperatives}

Chapter 1 of the Constitution sets out, as one of the founding provisions of the Constitution, the fact that the Republic of South Africa is one, sovereign, democratic state founded on the value of human dignity, the achievement of equality and the advancement of human rights and freedoms. ${ }^{13}$ Of no less significance is the fact that the Republic, as a sovereign, democratic state is founded on the supremacy of the Constitution and the rule of law. ${ }^{14}$ The right to equality is a self-contained right embodied in section 9 which provides that:

"(1) Everyone is equal before the law and has the right to equal protection and benefit of the law.

(2) Equality includes the full and equal enjoyment of all rights and freedoms. To promote the achievement of equality, legislative and other measures designed to protect or advance persons, or categories of persons disadvantaged by unfair discrimination may be taken.

(3) The state may not unfairly discriminate directly or indirectly against anyone on one or more of the following grounds, including race, gender sex, pregnancy, marital status, ethnic or social origin, colour, sexual orientation, age, disability, religion, conscience, belief, culture, language and birth.

(4) No person may unfairly discriminate directly or indirectly against anyone on one or more grounds in terms of subsection (3). National legislation must be enacted to prevent or prohibit unfair discrimination.

(5) Discrimination on one or more of the grounds listed in subsection (3) is unfair unless it is established that the discrimination is fair."

The concept that everyone has the individualistic right to religious freedom ${ }^{16}$ is contrasted by the associational right to religious freedom afforded to communities and organisations who are enjoined to enjoy such freedom and practice their religion provided they do not exercise their rights in a manner inconsistent with any provision of the Bill of Rights. ${ }^{19}$ In providing that everyone is equal before the law and has the right to equal protection and benefit of the law ${ }^{18}$ the Constitution may be conceived of as providing a formal approach to equality in so far as it assumes that in our constitutional dispensation all persons have been provided with equal rights

$S 1(a)$

S 1 (c).

15 For consideration of the vertical and horizontal application of the Bill of Rights see $s$ 8(2) and for further discussion on the topic see Du Plessis v De Klerk 1996 (3) SA 850 (CC) par 8; and AAA Investments v Micro Finance Regulatory Council 2006 (11) BCLR 1255 (CC). For further reading see De Vos South African Constitutional Law in Context (2015) 331337.

16 In terms of $s$ 15(1). For an analysis and argument on the close association between the terms "religion", "thought", "belief", "and "opinion" encountered in s 15(1) and the significance thereof in giving expression to the concept of religious freedom see article by author "Understanding the concept of 'religion' within the constitutional guarantee of religious freedom" in forthcoming publication of the Journal of South African Law.

17 Ss 31(1)(a) and (b) as read with 31(2).

$18 \mathrm{~S} 9(1)$. 
and can compete on an equal footing enabling like persons to be treated alike and unlike persons to be treated unlike. Axiomatic to such an approach is that the extension of equal rights to all persons would result in the elimination of inequalities that are manifest in the socio-economic landscape of our country. This approach is considered formalistic since the law of equality is applied equally and consistently to all individuals regardless of their situational circumstances. The rationale is that effect is given merely to the form of equality without actually making allowance for individual differences. Such an approach, and its propensity of taking into account likenesses shared between individuals is too parsimonious given its failure to take into account and embrace the differences between individuals, ${ }^{19}$ and the opportunity such different individuals should be given of being accommodated under the mantra of equal protection and benefit of the law in a democratic order. ${ }^{20}$ Substantive equality thus recognises that instead of treating all individuals as one and the same and applying laws consistently without distinction or discrimination, individuals must be accounted for in terms of their substantive worth and duly recognised on account of their differences which are required to be tolerated and accommodated in a pluralistic democratic order. Section 9 sets out the nature of equality envisaged and the measures to be taken in order to achieve same as well as to prevent and prohibit unfair discrimination. Section 9 does not expressly spell out that a substantive as opposed to a formal approach to equality is to be adopted. It is submitted that decisions of our constitutional court are testimony to adoption in general of a substantive approach to equality. ${ }^{21}$ This is underscored by the decision of the Constitutional Court in President of the Republic of South Africa $v$ Hugo, ${ }^{22}$ where it was stated that:

"We need to develop a concept of unfair discrimination which recognises that although a society which affords each human being equal treatment on the basis of equal worth ... we cannot achieve that goal by insisting upon identical treatment in all circumstances before that goal is achieved."

The Commission for the Promotion and Protection of the Rights of Cultural, Religious and Linguistic Communities ${ }^{24}$ (CPPRCRLC) is a juristic entity comprising a state institution supporting constitutional democracy. ${ }^{25}$ Aside from the issuing of media statements ${ }^{26}$ CPPRRCRLC has played a

19 Either on account of their social economic background or inherent personality traits, for example that they are of a particular cultural or social origin or because they hold particular religious beliefs.

20 See Minister of Home Affairs v Fourie 2006 (1) SA 524 (CC) par 60; Smith "Equality Constitutional Adjudication in South Africa" 2014 African Human Rights Journal 609612 and the authority cited at fn 17; and Grant "Constitutionalising Equality: The South African Experience" 2008 International Journal of Discrimination and the Law 201-249.

21 See National Coalition for Gay and Lesbian Equality v Minister of Justice 1999 (1) SA 6 (CC); Minister of Finance $v$ Van Heerden 2004 (6) SA 121 (CC) par 26; and Bato Star Fishing (Pty) Ltd v Minister of Environmental Affairs 2004 (7) BCLR 687 (CC).

221997 (4) SA 1 (CC).

23 Par 112.

24 Established in terms of ss $185-186$ of the Constitution.

25 As envisaged in terms of chapter $9, \mathrm{~s} 181$ of the Constitution.

26 See the media statement issued condemning COSAS's offensive actions relating to the 'pig's head' incident because it impacted adversely on the religious rights of individuals or 
rather muted role in the dynamic of religious-discrimination disputes in the workplace. ${ }^{27}$ In order to "deepen the culture of democracy established by the Constitution, Parliament may adopt charters of rights consistent with the provisions of the Constitution" ${ }^{28}$ Pursuant to this provision, the South African Charter of Religious Rights and Freedoms (the Charter) was adopted. ${ }^{29} \mathrm{~A}$ perusal of the preamble and wording of the Charter reveals an attempt on the part of the drafters to set out a detailed cornucopia of religious rights and interests on the part of individuals and organisations that warrant protection under the Constitutional guarantee of freedom of religion. ${ }^{30}$ Whilst the Charter is significant on account of the marked collaborative effort on the part of various stakeholders ${ }^{31}$ in ensuring its realisation it is noteworthy that to date there is no record of no reliance having been placed thereon in the determination of religious disputes by litigating parties or courts, tribunals or fora.

\section{Legislative regulations}

Two primary legislative sources regulating religious discrimination in the workplace are the LRA and the EEA. ${ }^{32}$ Complementary to these sources is the Promotion of Equality and Prevention of Unfair Discrimination Act (PEPUDA). ${ }^{33}$ PEPUDA must be interpreted in a manner that gives effect to the Constitution and its provision on equality. ${ }^{34}$ So too, must it give effect to any relevant law, such as the LRA or EEA or code of practice. ${ }^{35}$ PEPUDA aims at addressing unfair discrimination issues as they arise in sectors other than the workplace, whereas the LRA and EEA, as their names suggest, are directed at workplace-related unfair-discrimination matters. Accordingly, in so far as PEPUDA does not apply to the workplace ${ }^{36}$ it is submitted that the

communities in respect of whom pork is not their diet, Mabasa "Cultural, religious, and linguistic rights commission condemns "pig head" incident (http//www:gov.za.culturalreligious-and-liguistic-rights-commission-condemns-'pig head' incident) (accessed 2015-0406).

27 The role that CPPRRCRLC appears to play as a public platform in commenting upon prohibitive and offensive acts is nevertheless welcome as providing ongoing participatory dialogue on a topic of social interest.

28 S 234

29 Signed at the University of Johannesburg, Gauteng on 21 October 2010.

30 Either in terms of $\mathbf{9}$ or $\mathrm{s} 30$ of the Constitution.

31 For an interesting discussion on the history and content of the Charter see Coertzen "Constitution, Charter and religions in South Africa" 2014 African Human Rights LJ 126129.

32 When the EEA came into operation in August 1999 it replaced item 2(1)(a) of Schedule 7 of the LRA.

334 of 2000.

$34 \mathrm{~S} 3(1)$

35 It is submitted that whilst there is no code governing religious discrimination to be found in the LRA, EEA or PEPUDA, that it would not be inapposite to rely on the guidelines contained in the Charter.

36 In point of fact s 5(3) states that this Act (PEPUDA) does not apply to any person to whom and to the extent to which the EEA applies. See also Strydom v Chiloane 2008 ILJ 607 (T) par 11. 
detail of its content and provisions, save to the extent as dealt with below, is irrelevant to the ambit of this study. ${ }^{37}$

The LRA sets out its purpose thus:

"[...] to advance economic development, social justice, labour peace and the democratisation of the workplace by fulfilling the primary objects of [the LRA], which are -

a) to give effect to and regulate the fundamental rights conferred by section $23^{38}$ of the Constitution:

b) to give effect to the obligations incurred by the Republic as a member state of the International Labour Organisation [...]

Unfair discrimination by an employer against an employee ${ }^{40}$ on grounds of religion $^{41}$ constitutes an automatic unfair dismissal under the LRA. Unfair discrimination is provided for in section $187(1)(\mathrm{f})$ of the LRA which states:

"that the employer unfairly discriminated against the employee, directly or indirectly, on any arbitrary ground, including, but not limited to race, gender, sex, ethnic or social origin, colour, sexual orientation, age, disability, religion, conscience, belief, political opinion, culture, language, marital status or family responsibility".

In its preamble, the EEA states its purpose as being to:

"promote the constitutional right to equality and the exercise of true democracy;

eliminate unfair discrimination in employment;

[...] to redress the effects of discrimination; and ... give effect to the obligations of the Republic as a member of the International Labour Organisation".

\section{Section 3 of the EEA provides:}

"This Act must be interpreted -

(a) in compliance with the Constitution;

(b) so as to give effect to its purpose;

(c) taking into account any relevant code of good practice issued in terms of this Act or any other employment law; and

(d) in compliance with the international law obligations of the Republic, in particular those contained in the International Labour Organisation Convention (No. 111) concerning Discrimination in respect of Employment and Occupation."

Unfair discrimination in terms of the EEA is dealt with under the provisions of section 6(1) which that:

37 For further reading on PEPUDA see Du Toit et al Labour Relations Law: A Comprehensive Guide (2003) 542-543.

38 Which deals with labour relations and in particular sub-section (1) provides that everyone has the right to fair labour practices.

39 S 1.

40 Which would include an applicant for employment in terms of Wyeth v Manqele 200526 ILJ 749 (LAC) par 14, 45 and 52.

$41 \quad$ S 187(1)(f) read with ss 1 (b) and 3(c).

42 In s 3(d) express reference is made to the ILO Convention 111. 
"No person may unfairly discriminate, directly or indirectly, against an employee, in any employment policy or practice, on one or more grounds, including race, gender, sex, pregnancy, marital status, family responsibility, ethnic or social origin, colour, sexual orientation, age, disability, religion, HIV status, conscience, belief, political opinion, culture, language, birth or any other arbitrary ground."

Whilst the LRA refers specifically to an employer that is prohibited from unfairly discriminating against an employe ${ }^{43}$ the net of liability cast by the EEA is broadened with reference to "no person", thereby giving effect to the duty imposed upon the employer to take steps to promote equal opportunity in the workplace by eliminating unfair discrimination. ${ }^{44}$ Effectively, the employer can be held liable for conduct on the part of an employee against another employee which constitutes unfair discrimination. ${ }^{45}$ Juxtaposing the Constitutional provisions pertaining to unfair discrimination against those listed in the LRA and the EEA it is apparent that the Constitution lists seventeen grounds. ${ }^{46}$ In addition to the seventeen grounds listed in section 9(3) of the Constitution, the EEA has the grounds of HIV status, family responsibility and political opinion. Moreover, the extent of liability has been widened in the EEA by insertion of the words "or any other arbitrary ground". ${ }^{47}$ In similar vein, whilst HIV status is not mentioned as one of the listed grounds of unfair discrimination in terms of section 187(1)(f) of the LRA, ${ }^{48}$ the wording of the section "on any arbitrary ground, including, but not limited to ..." is sufficiently wide to include HIV status.

An employee who is dismissed in terms of section 187(1)(f) of the LRA may be entitled to a maximum sum of 24 months' compensation in the event of a successful adjudication of the matter in the Labour Court. ${ }^{49}$ Unlike the LRA, where a ceiling is set on compensation and the form of remedy, namely compensation or reinstatement, in terms of the EEA the Labour Court may, in addition to awarding compensation also award damages to be paid by the employer to the employee..$^{0}$ Under a section 187(1)(f) dispute the employee would be required to discharge the onus ${ }^{51}$ of proving a dismissal ${ }^{52}$ and unfair discrimination on the basis of religion. The onus would rest on the employer $^{53}$ of showing that the dismissal on grounds of religion was fair due to the inherent requirements of the job, ${ }^{54}$ or that accommodating the employee's religion would work an undue hardship against the employer. ${ }^{55}$

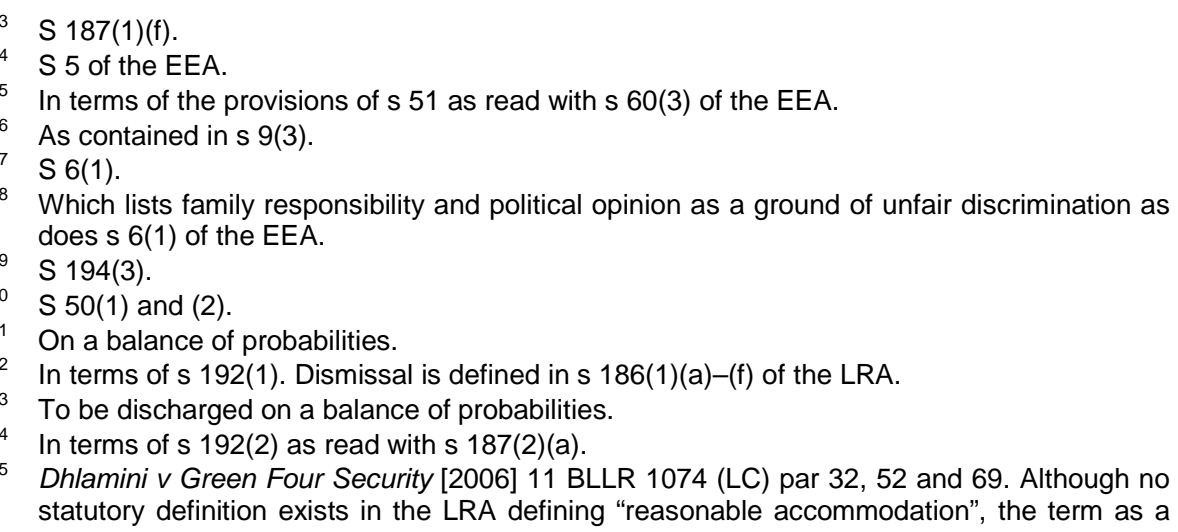


The burden of proof in disputes under section 6(1) of the EEA are set out in section 6(11) thus:

“(1) If unfair discrimination is alleged on a ground listed in section 6(1), the employer against whom the allegation is made must prove, on a balance, that such discrimination -

(a) did not take place as alleged; or

(b) is rational and not unfair, or is otherwise justifiable.

(2) If unfair discrimination is alleged on an arbitrary ground, the complainant must prove, on a balance of probabilities, that -

(a) the conduct complained of is not rational;

(b) the conduct complained of amounts to discrimination; and

(c) the discrimination is unfair."

Clearly the aforementioned section places a burden on the employer, when faced with an unfair-discrimination allegation on a listed ground, such as religion, of disproving that the discrimination took place, alternatively to show that the action taken was rational, fair or justified. A noteworthy aspect of the recently amended EEA ${ }^{56}$ is the extent to which the ambit of grounds of defence have been widened. Prior to the amendment whenever unfair discrimination was alleged in terms of the EEA, the employer against whom the allegation was made was required to "establish that the [discrimination] was fair". ${ }^{57}$ In terms of the recent amendment, an employer is now given extended leverage in refuting a claim of unfair discrimination. The complainant, on the other hand, when alleging discrimination upon an arbitrary ground is saddled with having to show that the measure or action is irrational, discriminatory and unfair. Conceivably a complainant would be illadvised to pursue a complaint couched in terms of discrimination based on an arbitrary ground in lieu of the onerous burden of proof. Accordingly, complainants may be encouraged to rather exhaust the remedies afforded under the listed grounds of unfair discrimination. ${ }^{58}$ This increased basis of defence has been the subject of academic criticism, not least since no support for the widened defence can be found in the wording of the Convention. ${ }^{59}$ How these new provisions will be interpreted by our courts is moot. ${ }^{60}$

ground upon which the employer is required to prove that discrimination is fair by showing what steps have been taken to reasonably accommodate diversity appears in $s 14(3)(i)$ (ii) of PEPUDA. For further discussion of this term and the extent of its use see Henrico "Mutual Accommodation of Religious Differences in the Workplace - A Jostling of Rights" 2012 Obiter 503.

56 As amended by the Employment Equity Amendment Act 47 of 2013.

57 S 11.

58 Sustenance for this view may be taken from the fact that despite the fact that $s 187(1)(f)$ also provides for a claim to be brought on any other arbitrary ground, to date there is no reported case evidencing the pursuit of such a claim.

59 For criticism of the amendments see Submission on the Employment Equity Amendment Bill of 2012 (As introduced by the Minister of Labour (National Assembly)) http://www.pmg.org.za/files/130807dutoit.pdf (accessed 2015-04-07); and Du Toit "Protection Against Unfair Discrimination: Cleaning Up the Act" 2014 ILJ 26232634.

60 See comments by Van Niekerk and Smit Law@work 132; and Du Toit and Potgieter Unfair Discrimination in the Workplace (2014) 17. 
The International Labour Organisation (the ILO) obligation relevant to the EEA and LRA is Convention 111 of $1958^{6}$ (the Convention). The Convention provides that:

"For the purpose of this Convention the term discrimination includes -

a) any distinction, exclusion or preference made on the basis of race, colour, sex, religion, political opinion, national extraction or social origin, which has the effect of nullifying or impairing equality of opportunity or treatment in employment or occupation; b) $[\ldots]$

2 Any distinction, exclusion or preference in respect of a particular job based on the inherent requirements thereof shall not be deemed to be discrimination."

Another international obligation relevant to the EEA and LRA is the United Nations Universal Declaration of Human Rights ${ }^{64}$ (the Declaration) which prohibits all forms of discrimination. Article 7 of the Declaration provides that:

"All are equal before the law and are entitled without any discrimination to equal protection of the law. All are entitled to equal protection against any discrimination in violation of this Declaration and against incitement to such discrimination."

It is incumbent upon courts, tribunals and fora, when interpreting legislation to give effect to customary international and international law. ${ }^{65}$ The Convention is an instrument forming part of international law, ${ }^{66}$ the contents of which would warrant being considered when adjudicating upon disputes involving the interpretation ${ }^{67}$ of religious discrimination arising from a contravention of either the LRA ${ }^{68}$ or the EEA. ${ }^{69}$ Common to both the LRA and the EEA is their apparent obligation to give effect to obligations incurred by the Republic as a member state of the ILO. The directive contained in section 9(4) of the Constitution that national legislation must be enacted to prevent or prohibit unfair discrimination means that once such national legislation has been passed, litigants cannot by-pass such legislation and rely directly upon the Constitution since this would be contrary the principle

61 Convention on Discrimination (Employment and Occupation) ratified by South Africa on 5 March 1997. For further comment and discussion see Hlongwane "Commentary on South Africa's Position Regarding Equal Pay for Work of Equal Value" 2007 Law, Democracy \& Development 6971.

62 Article 1 (a) (author's own emphasis).

63 Article 2

64 Adopted by the General Assembly on 10 December 1948.

65 In terms of s 232 and 233 of the Constitution, subject to the proviso that such law is not unreasonable or out of kilter with the values and principles of the Bill of Rights. For further reading see Prinsloo v van der Linde 1997 (3) SA 1012 CC par 19 and 20.

66 See Currie and De Waal The Bill of Rights Handbook (2010) 574-575.

67 For further reading on interpretation methods to be employed see Cornell and Friedman "In Defence of the Constitutional Court: Human Rights and the South African Common Law" 2011 Michigan LJ 19.

$68 \mathrm{~S} 187(1)(\mathrm{f})$.

69 S 6(1). 
of subsidiarity. ${ }^{70}$ Hence employees pursuing claims against their employer's alleging unfair discrimination cannot rely directly on the provisions of section 9 of the Constitution but must rely on the provisions of the EEA or the LRA. ${ }^{71}$

Since employees are required to rely directly on statutory provisions aimed at eliminating discrimination, instead of the Constitutional provision contained in section 9, they are in a sense afforded additional or wider grounds upon which to base their claims. ${ }^{72}$ In addition, employees are afforded the additional ground of establishing discrimination on the basis of any arbitrary ground.

It is clear from the aforesaid that religious discrimination disputes, as they arise in the South African workplace, are indeed highly regulated not only in terms of the overriding Constitutional imperative of equality that is to be promoted and against which discrimination is proscribed, but particularly in terms of national legislation which sets out the basis upon which claimants may claim relief in addition to the remedies available in the event of a successful claim. The right to equality which is the imperative captured in section 9 of the Constitution is given effect to through the EEA and LRA which proscribe acts of unfair discrimination which detract and impact upon the claimant's right to equality. Moreover, by means of the interpretive provisions contained in the Constitution and echoed in the EEA and LRA the spirit of the Convention is captured which seeks to advance and uphold equality of opportunity or treatment in employment or occupation.

\section{Understanding discrimination as differentiation and establishing discrimination as a ground of discrimination in the context of the equality imperative and the interpretation thereof}

Nationally and globally the strife is constant to eradicate and address conduct, the effect of which results in unequal treatment of human beings in general and workers or employees specifically. ${ }^{74}$ The link between the notion of equality and discrimination is inexorable on account of the fact that prima facie discrimination is anathema to equality. Embroidered into this link is also the close association between equality and human dignity. Put differently "[e]very human being has an absolute inner worth. Because this worth is absolute all human beings are equal to one another with regard to this

70 Du Plessis "Subsidiarity': What's in the Name for Constitutional Interpretation and Adjudication?” 115 http://www.chr.up.za/chr_old//closa/chapters/Subsidiarity.pdf (accessed 2015-04-08).

71 See S v Mlungu 1995 (3) SA 867 (CC) par 95; Minister of Health v New Clicks SA (Pty) Ltd 2006 (2) SA 311 (CC) par 437; and SANDU v Minister of Defence 2007 (5) SA 400 (CC) par 51.

72 Namely HIV status, political opinion and family responsibility as provided for by the EEA, or political opinion and family responsibility as provided for by the LRA.

73 Provided for by $s 6(1)$ of the EEA and $s$ 187(1)(f) of the LRA. Although usage of this additional ground does not appear to be without its problems.

74 See Hepple Equality: The New Legal Framework (2011) 13; and Meyerson Jurisprudence (2011) 303310 
absolute worth. This absolute worth is dignity". ${ }^{75}$ Our legal understanding of discrimination, however, has taught us to distinguish between discrimination (differentiation) $^{76}$ in the pejorative and non-pejorative sense. In the pejorative sense discrimination is understood to mean a differentiation (distinction) made on a basis that is hurtful, bad, arbitrary, unfair, capricious or objectionable, whereas in the non-pejorative sense discrimination is understood to mean differentiation (distinction) made on a basis that is fair, reasonable, justifiable, objective or non-objectionable.

In neither the Constitution nor national legislation is discrimination defined. A definition is, however, provided in terms of the Convention which refers to "discrimination" as a "distinction, exclusion or preference [...] which has the effect of nullifying or impairing equality of opportunity or treatment in employment or occupation". 77 This definition does not fall outside the parameters of equality as conceived of in terms of section 9 of the Constitution. ${ }^{78}$ Moreover, it is also one which is and ought to be given effect to by the EEA and the LRA in discharging the ILO obligations. ${ }^{79}$ Prior to the coming into operation of the LRA and the EEA the aforementioned definition was used in the interpretation of the interim Constitution ${ }^{80}$ prohibition on unfair discrimination as pointed out by Du Toit ${ }^{81}$ in the matter of Association of Professional Teachers $v$ Minister of Education, ${ }^{82}$ where the following was stated:

"Where the criteria for a differentiation or classification are reasonably justifiable and objective, such differentiation will not necessarily constitute discrimination. Put differently, where the ... differentiation is not based on an objective ground and such differentiation has the effect of nullifying or impairing the recognition, enjoyment or exercise by all persons on an equal footing of all rights and freedoms, it would constitute discrimination.

The role played by the Industrial Court in the adjudication of discrimination disputes and the jurisprudence of the unfair labour practices in the 1980s was a precursor the development of the term "discrimination" being extended to include unfair discrimination. ${ }^{84}$ This was galvanised when the definition of an "unfair labour practice" was amended to include "unfair discrimination by an employer against an employee solely on the grounds of race, sex or creed". ${ }^{85}$ The term "unfair discrimination" was used by the

75 Ackermann Human Dignity: A Lodestar for Equality in South Africa (2013) 56. Also see AZAPO v President of the Republic of South Africa 1996 (4) SA 671 (CC) par 1.

76 See Du Toit and Potgieter Unfair Discrimination in the Workplace 18 and 79-82 who argue correctly, it is submitted, that discrimination can be used interchangeably with the term differentiation.

Article $1(a)$.

78 Du Toit and Potgieter Unfair Discrimination in the Workplace 18.

$\mathrm{S} 3(\mathrm{~d})$ and 1 (b) of the EEA and LRA respectively.

Of 1993.

Du Toit and Potgieter Unfair Discrimination in the Workplace 18.

199516 ILJ 1048 (IC).

Association of Professional Teachers v Minister of Education supra 1050.

84 Du Toit and Potgieter Unfair Discrimination in the Workplace 9 and the authorities cited at fn 3.

85 In terms of $\mathrm{s} 1$ of the Labour Relations Act 28 of 1956, as amended by the Labour Relations Amendment Act 83 of 1988. For further reading see Du Toit and Potgieter Unfair 
drafters of the interim Constitution ${ }^{86}$ and subsequently adopted in section 9 of the Constitution. It has been pointed out that since the word "discrimination" has both a pejorative and benign meaning express steps were taken to ensure that by inserting the adjective "unfair" the intention was to assert a prohibition in respect of differential (discriminatory) acts that are objectionable. ${ }^{87}$ Essential to the concept of unfair discrimination is the role it plays in enforcing the right to equality and human dignity. ${ }^{88}$ This is due to the fact that a person required to suffer the hurtfulness of being treated differently or discriminated against on the mere basis of her religion in a manner that is capricious or arbitrary suffers the impunity that such conduct has upon her dignity and self-worth as an individual.

Section 9(3) of the Constitution specifies certain grounds upon which, if discrimination is shown to have taken place, it is presumed to be unfair unless the respondent can establish that the discrimination was fair. ${ }^{90}$ In terms of the EEA where an allegation of unfair discrimination is made on a listed ground, ${ }^{91}$ we have seen how the respondent is required to prove that such discrimination did not take place, is not rational and not unfair or is justifiable. ${ }^{92}$ In terms of the LRA, a dismissal in terms of section 187(1)(f) may be fair if the reason for it is based on an inherent requirement of the job. ${ }^{93}$ These specified grounds upon which unfair discrimination can take place is of particular significance on account of the fact that they pertain to "immutable biological attributes or characteristics of people" or "to the intellectual, expressive and religious dimensions of humanity". ${ }^{44}$ A notable feature of the specified or listed grounds of discrimination is the fact that apart from religion being part of this group, they can arguably be considered to be the main basis upon which unfair-discrimination disputes are adjudicated. A reason that has been advanced for this is due to the extensive nature of grounds set out in the EEA and the fact that the listed

Discrimination in the Workplace 10; and Du Toit "The Prohibition of Unfair Discrimination: Applying S 3(d) of the Employment Equity Act 55 of 1998" in Dupper and Garbers (eds) Equality in the Workplace: Reflections from South Africa and Beyond (2009) 139142.

86 As it appeared in s 8(2).

87 This is understandable in the context of South Africa emerging as a country from a society with a history of racial discrimination and intolerance which gave impetus to socio-economic and political conflict and disharmony. See Dugard Human Rights and the South African Legal Order (1978); and Mathews Freedom, State, Security and the Rule of Law (1986). See also Davis, Cheadle and Haysom Fundamental Rights in the Constitution (1997) 56; and Currie and De Waal The Bill of Rights Handbook 244.

88 Du Toit and Potgieter Unfair Discrimination in the Workplace 20. See also $S v$ Makwanyane 1995 (6) BCLR 665 (CC) par 326; Prinsloo v Van der Linde supra par 31; Brink v Kitsoff NO 1996 (4) SA 197 (CC) par 42; Harksen v Lane supra par 49; Bato Star Fishing v Minister of Environmental Affairs 2004 (4) SA 490 (CC) par 73-75; and Albertyn "Equality" in Cheadle et al (eds) South African Constitutional Law: The Bill of Rights (2002) 105.

89 For further reading see Henrico "The Role Played by Dignity in Religious-discrimination Disputes" 2014 Obiter 24.

90 See s $9(5)$.

91 In s 6(1).

$92 \mathrm{~S} 11(1)(\mathrm{a})$ and $(\mathrm{b})$.

$93 \mathrm{~S}$ 187(2)(a).

94 Harksen $v$ Lane supra par 49. 
grounds lend themselves to being interpreted generously. ${ }^{95}$ It is submitted, however, that a reason for more cases being brought on specific or listed grounds may well be attributed to the less onerous duty of proof upon the claimant, namely of merely being required to prove on a balance the fact that a differentiation (discrimination) took place on a specified ground, in which event unfair discrimination is presumed.

The Harksen $v$ Lane case is seminal for having established the so-called three-stage enquiry into the violation of equality which sets out the test thus:

“(a) Does the provision differentiate between people or categories of people? If so ...

(b) Does the differentiation amount to unfair discrimination? This requires a two-stage analysis:

(i) Firstly, does the differentiation amount to 'discrimination'? If it is on a specific ground, the discrimination will have been established. If it is not on a specific ground, then whether or not there is discrimination will depend upon whether, objectively, the ground is based on attributes and characteristics which have the potential to impair the fundamental human dignity of persons as human beings or to affect them adversely in a comparably serious manner.

(ii) If the differentiation amounts to 'discrimination', does it amount to 'unfair discrimination'? If it has been found to have been on a specific ground then unfairness will be presumed. If on an unspecific ground, unfairness will have to be established by the complainant. The test of unfairness focuses primarily on the impact of the discrimination on the complainant and others in his or her situation.

If, at the end of the enquiry, the differentiation is found not to be unfair, then there will be no violation ...

(a) If the discrimination is found to be unfair then a determination will have to be made as to whether the provision can be justified under the circumstances of the limitations clause."

What has become known as the Harksen test has been adopted by the labour courts for many years ${ }^{97}$ Du Toit has criticised the test as formulated in Harksen with reference to the equality provision of the interim Constitution ${ }^{98}$ which has since been adopted by the Labour Court and practitioners as the so-called panacea of all tests and applied to the determination of discrimination disputes within the purview of a private employment relationship. The cause for concern is two-fold. First, by relying directly on the Constitution, claimants are by-passing national legislation and contravening the principle of subsidiarity as was the case in Stokwe $v$ MEC, Department

See Van Niekerk and Smit Law@work 127-128 and the authorities cited at fn 55.

Harksen $v$ Lane supra par 50.

97 Van Niekerk and Smit Law@work 131. For some cases in which the Harksen test was employed see Louw v Golden Arrow Bus Service (Pty) Ltd 1999 ZALC 166 par 26; Hoffmann v SAA 2001 (1) SA 1 (CC) par 24; NUMSA v Gabriels (Pty) Ltd 200223 ILJ 2088 (LC) par 9; FAWU v Pets Products (Pty) Ltd 2000 ZALC 25 par 13; Khosa v Minister of Social Development 2004 (6) SA 505 (CC) par 70; IMATU v City of Cape Town [2005] 11 BLLR 1084 (LC) par 80; and Lesbian and Gay Equality Project v Minister of Home Affairs 2006 (1) SA 524 (CC) par 110.

$98 \mathrm{~S} 8$, now S 9 of the Constitution, which was used in order to test the constitutional validity of certain provisions of the Insolvency Act 24 of 1936. 
of Education, Eastern Cape ${ }^{99}$ in which the applicant relied directly upon sections 9 and 23 of the Constitution ${ }^{100}$ in alleging language discrimination instead of employing the relevant provisions of the LRA ${ }^{101}$ and the EEA. ${ }^{102}$ Despite this, Stokwe relied on the Harksen test and was successful in the Court upholding the claim. ${ }^{103}$ Second, by referring to Harksen to obtain a definition of unfair discrimination in the employment context is undesirable and inappropriate since the Convention already contains a definition of discrimination and because the EEA and LRA are required to be interpreted in a manner that gives effect to the ILO obligations (in general) and the Convention (specifically) it follows that discrimination for purposes of the abovementioned national legislation must be given the same definition as the Convention, making it nugatory to resort to Harksen for a definition. ${ }^{104}$ Such criticism that has been made by Du Toit against defining employmentrelated discrimination disputes through the lens of the definition offered in the Harksen case is convincing and valid given the reasons advanced. Whilst the learned authors Van Niekerk and Smit agree with Du Toit in this regard they appear to suggest that the second stage of the Harksen enquiry should not be as readily eschewed since it would eliminate the determination into the unfairness of the discrimination. ${ }^{105}$ Perhaps the most suitable course to adopt, in navigating between this jurisprudential Scylla and Charybdis, is for our courts to be context sensitive to the nature of the dispute, thereby ensuring that the:

- dispute is considered and dealt with in the employment context;

- parties do not subvert the principle of subsidiarity by refusing to consider any application or claim based directly on the Constitution; ${ }^{106}$

- definition attributed to discrimination is consistent with the Convention as given effect to by the EEA and LRA;

- failure on the part of the Convention to provide a means of determining the unfairness of the discrimination entitles the court to take into account relevant jurisprudence of previous decisions which considered the impact of unfair discrimination upon the right to equality and human dignity. ${ }^{107}$

99 [2005] 8 BLLR 822 (LC).

100 Par 9.

101 Item 2(1)(a) of Schedule 7 (residual unfair labour practices).

$102 \mathrm{~S} 6$.

103 Par 25.

104 For a general discussion of the above critique see Du Toit in Dupper and Garbers (eds) Equality in the Workplace: Reflections from South Africa and Beyond 151-152; Du Toit 2014 ILJ 2623 2634; and Du Toit and Potgieter Unfair Discrimination in the Workplace 14 and 16-17.

105 Van Niekerk and Smit Law@work 131.

106 Unless of course a litigant is directly challenging the validity of a provision of the Constitution.

107 Author's own emphasis. Conceivably a case which is not employment-related may still be relevant to an employment-related dispute where the nexus between the two cases in question is based on unfair discrimination. A case in point is Mangena $v$ Fila South Africa (Pty) Ltd [2009] 12 BLLR 1224 (LC), which concerned itself with an application based on s $6(1)$ of the EEA wherein the applicant alleged unfair discrimination on the basis of race or 
It is important to emphasise that if the equality imperative as borne out by section 9 of the Constitution is to be given proper effect to and complainants afforded the opportunity of exercising their constitutional rights against unfair discrimination through the channels of national legislation that due regard is had to the context-sensitive nature of the dispute which duty is borne by the court, tribunal or fora. As such it would be incumbent on presiding officers and judges when interpreting the EEC and LRA to do so in a manner that gives effect to section 39(2) of the Constitution, meaning that the legislation must be interpreted in a manner that promotes the spirit, purport and objects of the Bill of Rights. ${ }^{108}$ However, in reality the dynamics of each case are such that seldom can the extent to which the court will adopt a specific test be predicted when adjudicating a specific dispute. Support for this appears from the cases considered below.

\section{Consideration of three cases}

It is not the intention of this paper to give a rendition of the jurisprudential position of case law on religious-discrimination disputes. ${ }^{109}$ The cases discussed hereunder are used as a vignette of what has thus far been reported pertaining to workplace-religious discrimination. The rationale for analysing these cases is to point out that no universal patina is being employed by the courts in the determination of unfair-discrimination disputes in general.

In Strydom v NG Gemeente Moreleta Park ${ }^{110}$ the applicant could not rely on the EEA or the LRA since he had been contracted by the church to teach music to post-matric students. Upon discovering that Strydom was in a homosexual relationship the church terminated his contract of services as an independent contractor. Strydom contested the termination on the basis of PEPUDA. ${ }^{111}$ In contesting the claim the church sought to rely on its Constitutional right to freedom of religion, arguing that it was an inherent requirement of the job by someone in Strydom's position that he could not live in a homosexual relationship since same was out of keeping with the doctrine of the church, ${ }^{112}$ requiring its leadership to teach its doctrines. Owing to the fact that Strydom was not in a leadership position and only

colour (par 2) and in which Van Niekerk J, referred to Harksen as authority for establishing unfair discrimination (par 5).

108 See Budlender "Transforming the Judiciary: The Politics of the Judiciary in a Democratic South Africa" 2005 SALJ 715; Fagan "S 39(2) and Political Integrity" 2004 Acta Juridica 117; and Langa "Transformative Constitutionalism" 2006 Stellenbosch LR 351.

109 For further discussion in this regard see Henrico 2012 Obiter 503; and Van Niekerk and Smit Law@work.

110200930 ILJ 868 (EqC) and in which the Harksen test was not considered.

111 Although the case falls within the parameters of PEPUDA and thus outside the employment relationship, the relevance to the subject matter of this article is the extent to which the church raised, as a defence, the inherent requirements of the job in addition to the consideration of the impact of unfair discrimination upon equality and human rights. For further discussion see De Freitas "Freedom of Association as a Foundational Right: Religious Associations and Strydom v Nederduitse Gereformeerde Gemeente, Moreleta Park" 2012 SAJHR 258-272.

112 Par 15. 
taught music to the children, the Court attached more weight to the impairment of the applicant's dignity by virtue of the termination of his contract $^{113}$ which impacted adversely upon the applicant in that it resulted in his suffering from depression, being unemployed, being the subject matter of publicity and having to sell his piano. ${ }^{114}$ In point of fact the applicant was awarded an amount of R75 000.00 for the impairment of his dignity. ${ }^{115}$ This impairment arose out of the principal action of being discriminated against on the ground of sexual orientation due to the church's alleged insistence on abiding by its religious convictions. This case highlights the important consequence of being subject to treatment that unfairly discriminates against one and ultimately does not make allowance for one's diversity or differences to be accommodated in a manner that can give substantive effect to equality. ${ }^{116}$ As previously stated human dignity is at the core of equality and therefore when unequal conduct has been meted out in a manner that is disparaging or not in accordance with the spirit and purport of the values of our Bill of Rights, such conduct strikes at the very heart of the human being adversely impacting upon her dignity.

In the Department of Correctional Services v POPCRU, ${ }^{118} 21$ prison warders were dismissed for refusing to cut their dreadlocks. The dismissed employees insisted that their hairstyles were consistent with their Rastafaria belief and religion and cutting same would infringe their rights, therefore rendering their dismissals automatically unfair on grounds of religious discrimination in terms of the LRA. ${ }^{119}$ In deciding the appeal, the SCA considered the claim, correctly so, it is submitted, to have been on a listed ground, and with reference to the Harksen test Maya JA observed that:

"Once discrimination has been established on a listed ground, unfairness is presumed, and the employer must prove the contrary. Relevant considerations in this regard include the position of the victim of the discrimination in society, the purpose sought to be achieved by the discrimination, the extent to which the rights or interests of the victim of the discrimination have been affected, whether the discrimination has impaired the human dignity of the victim, and whether less restrictive means are available to achieve the purpose of the discrimination.

It is clear that the case was decided squarely within the four corners of the LRA and specifically the claim under which the applicants had sought relief, namely section $187(1)(f) .{ }^{121}$ The fact that Harksen was referred to as

113 Par 33, where a link is made between the impairment of dignity due to the nature of the discrimination which was all-encompassing.

114 Par 33.

115 Par 37.

116 Par 25 Basson J, stated that: "the fact of being discriminated against on the ground of his homosexual orientation had an enormous impact on the complainant's right to equality, protected as one of the foundations of our new constitutional order. Likewise, his right to dignity is seriously impaired due to the unfair discrimination".

117 Henrico 2014 Obiter 24.

1182013 ZASCA 40.

119 S 187(1)(f) and par 10.

120 Par 21. Footnotes excluded.

121 Par 23. 
authority for relevant factors to be considered when determining unfairness merely underscored and reinforced the imperative of equality and intrinsic worth of human dignity impacted upon in cases of unfair discrimination.

Dhlamini $v$ Green Four Security ${ }^{122}$ concerned the dismissal of security guards for refusing to shave their beards on the basis that a beard was an inherent tenet of their religious belief. The applicants alleged that their dismissal constituted a dismissal under section 187(1)(f) of the LRA. ${ }^{123}$ Pillay $\mathrm{J}$, made the observation that, although the applicants had pleaded their case in terms of the LRA and that litigants were in general encouraged to rely on national legislation instead of relying directly on the Constitution, Pillay $\mathrm{J}$, went on to consider the case as an exception to the subsidiarity rule and stated that "the source of the right [allegedly infringed] is the Constitution". ${ }^{124}$ Underscoring the Court's reasoning was a "constitutional approach" that was adopted in determining not only whether there had been discrimination ${ }^{125}$ but whether the shaving of beards as demanded by the employer was an inherent requirement of the job which would not be deemed to be discrimination in terms of the provisions of article 1(2) of the Convention. ${ }^{126}$ Moreover, since the applicants had never contended that the respondent failed to reasonably accommodate this was not an issue upon which the Court was called to make a finding. ${ }^{127}$ The Dhlamini case is testimony to an employment-discrimination dispute involving religion in which the Harksen case was not employed. Notwithstanding, the absence of the Harksen case as the usual judicial formula employed to determine discrimination disputes, the Court itself insisted upon deciding the dispute through the lens of a constitutional framework despite the fact that the claimants had pleaded their case on the basis of section 187(1)(f) of the LRA. It is submitted that Pillay J, cannot be faulted with the observation that "one of the objectives of the LRA is to give effect to the fair labour-practice provision of the Constitution, which includes the right not to be discriminated [against] s 1(a) of the LRA" ${ }^{\prime 28}$ and that "the LRA must be interpreted in compliance with the Constitution". ${ }^{129}$ What remains puzzling and somewhat concerning is the extent to which Pillay $\mathrm{J}$, jettisoned deciding the case as pleaded, ${ }^{130}$ namely on the basis of section 187(1)(f) of the LRA, and proceeded to deal with the matter purely and substantively as a constitutional matter.

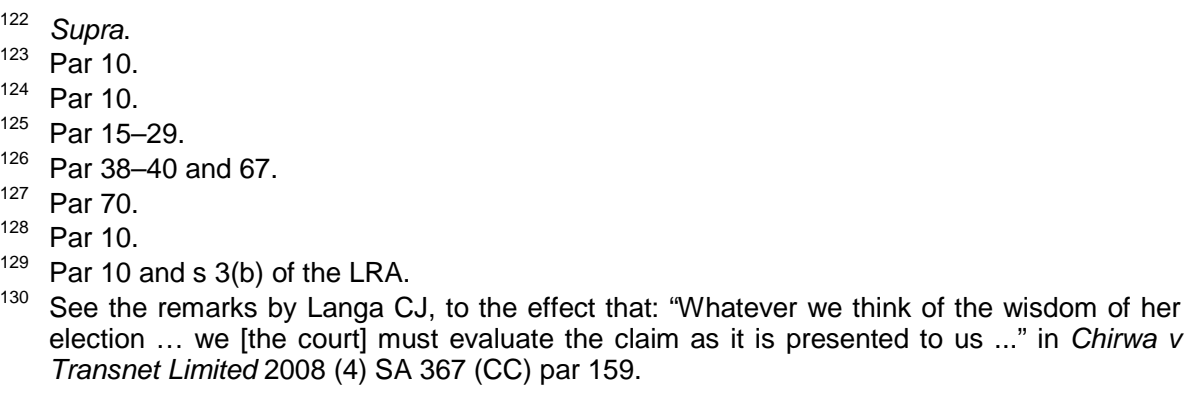

130 See the remarks by Langa CJ, to the effect that: "Whatever we think of the wisdom of her election ... we [the court] must evaluate the claim as it is presented to us ..." in Chirwa $v$ Transnet Limited 2008 (4) SA 367 (CC) par 159. 


\section{CONCLUDING REMARKS}

The South African constitutional and legislative framework on equality is significant. A premium is placed on the notion of equality contained in section 9 of the Constitution as borne out by the fact that our jurisprudence endorses a substantive and not a formal concept of equality. This ensures that proper and full account is taken of persons irrespective of their socioeconomic position and situation. Put differently, more room is made for a greater number of individuals to be included on account of their differences which must not be excluded but rather celebrated in a democratic order. Moreover, discrimination is dealt with in terms of the imperatives of "unfair discrimination" ensuring that a distinction is drawn between differentiation on objectionable (pejorative) grounds and non-objectionable (benign) grounds. In place is a highly-regulated framework cemented together first and foremost by the tenets of the Constitution embracing a generous view of equality. Giving effect to the constitutional imperative of equality is the national legislation in the form of the EEA and LRA which also gives effect to Covenant 111 of the ILO. As with all other disputes in the workplace, religious-discrimination disputes demand expedient resolution in order to ensure the stability of a harmonious working environment between the employee and employer. ${ }^{131}$ Unique to religious-discrimination disputes is the potential they have of impacting upon the rights of equality and human dignity, thereby elevating the nature of dispute to one of a peculiarly sensitive nature. For this reason adjudicators of workplace religious-discrimination disputes are required to adopt a context-sensitive approach. They are encouraged to do so on account of the formal South African regulated constitutional and legislative framework; a framework which seeks to eradicate the injustice caused by unfair discrimination by guaranteeing the promotion of Constitutional equality. The shadow of the Harksen three-stage test of determining discrimination disputes continues to loom larger over the way in which practitioners and even judges determine the way in which applications and pleadings are to be couched. However, what matters more is that when adjudicating such disputes, the Court, tribunal or fora adopts a context-sensitive approach. From the cases viewed it would appear that there is no stencil or strict test being adopted in the determination of religious-discrimination disputes. Whether this bodes well for future cases will need to be viewed in terms of the nature of decisions handed down.

131 Knight "The Effectiveness and Consistency of Disciplinary Actions and Procedures within a South African Organisation" 2014 Mediterranean Journal of Social Sciences 589593. 